\title{
Tradição oral e usos da memória: o caso do Tribunal de Uaitangi, nova Zelôndia'
}

Verena Alberti

\begin{abstract}
Resumo: Em 1840 foi assinado, na Nova Zelândia, então colônia da Inglaterra, o Tratado de Waitangi, entre a Coroa britânica e mais de quinhentos chefes maori. Em seus três artigos, o documento, escrito em inglês e traduzido para o maori por missionários britânicos, determinava que os maori cederiam o governo da região à Grã-Bretanha, tendo garantido seu direito a terras, florestas e áreas pesqueiras. $\mathrm{Na}$ história da Nova Zelândia, contudo, o tratado acabou se constituindo em letra morta, e os maori foram perdendo suas terras, ficando confinados a regiões pouco férteis. Nos anos 1970, uma série de fatores levou a mobilizações dos maori, que culminaram na criação do Tribunal de Waitangi, em 1975, instância na qual podem ser denunciadas ações ou omissões da coroa, inclusive após a independência da Nova Zelândia, que tenham rompido as promessas do Tratado de 1840. No julgamento, as "provas orais", ou seja, a tradição oral dos grupos que reivindicam um território ou o direito a uma atividade econômica, desempenham papel importante.
\end{abstract}

\footnotetext{
* Pesquisadora do Programa de História Oral do Centro de Pesquisa e Documentação de História Contemporânea do Brasil (CPDOC) da Fundação Getulio Vargas e professora de história da Escola Alemã Corcovado, no Rio de Janeiro. Formada em história pela UFF, mestre em antropologia social pelo PPGAS do Museu Nacional/ UFRJ e doutora em teoria da literatura pela Universidade de Siegen, Alemanha. verena.alberti@fgv.br.
}

Anos 90, Porto Alegre, v. 14, n. 26, p.19-39, dez. 2007 
Este texto trata do caso do Tribunal de Waitangi e de suas relações com temas como tradição oral, usos do passado e identidade nacional.

Palavras-chave: Memória. Tradição oral. Usos do passado. Identidade Nacional. Nova Zelândia.

O objeto deste texto - a história do Tratado e do Tribunal de Waitangi, na Nova Zelândia - é tão interessante que parece feito "sob encomenda" para se pensar questões como usos do passado, tradição oral, memória e política. Em Wellington, capital da Nova Zelândia, existe um museu nacional chamado Te Papa ("Our Place”), fundado em fevereiro de 1998, e cujo projeto de criação teve início em $1988 .^{2}$ É um museu recente, portanto, que acaba de completar dez anos. Uma de suas exposições permanentes chama-se "Signs of a Nation". O visitante percorre espaços de interação multimídia, ouve opiniões sobre o Tratado de Waitangi e tem a oportunidade de ver uma reprodução ampliada do documento, em inglês e em maori. O museu tem o claro propósito de ser um museu nacional, reunindo manifestações, documentos, registros, objetos e histórias que parecem procurar responder de forma plural à pergunta sobre qual seria, na Nova Zelândia, a identidade nacional.

O Tratado de Waitangi foi firmado em 1840 entre a coroa britânica e cerca de quinhentos chefes maori. ${ }^{3}$ Os maori, originários da Polinésia, chegaram às ilhas que hoje formam a Nova Zelândia no século X. Chamaram a ilha do Norte de Aotearoa, cuja tradução pode ser "terra das longas nuvens brancas". Em 1642, o holandês Abel Tasman chegou ao arquipélago e, em 1769, o navegador James Cook reivindicou-o para a coroa britânica. No início do século XIX, cerca de 80 mil maori viviam nas duas ilhas da Nova Zelândia. Eles não se percebiam como uma "nação", e sim como diferentes "hapu", subtribos, que muitas vezes faziam guerras entre si. Antes da assinatura do tratado, a ocupação pelos colonos era desordenada e havia sinais de interesse dos franceses pela região. A coroa britânica percebeu, então, que anexar o território poderia regular os assuntos de interesse da Inglaterra, inclusive o comércio. Em 
poucos dias, agentes do governo britânico prepararam o documento, traduzido para o maori por um missionário e seu filho, na noite de 4 de fevereiro de 1840. O documento foi debatido por cerca de quinhentos maori durante um dia e uma noite, na baía de Waitangi - daí seu nome.

Três artigos compõem o tratado. Pelo primeiro, os maori cediam à coroa britânica "todos os direitos e poderes de soberania". "Soberania", contudo, foi traduzido para "kawanatanga", "governo", e não incluía a autoridade tradicional dos chefes ("rangatiratanga"). De acordo com a versão traduzida, os maori cediam à coroa o completo governo sobre suas terras, mas mantinham o direito de administrar seus próprios assuntos. Pelo artigo segundo, a coroa garantia aos maori plenos direitos sobre suas terras, florestas, pesca e outras propriedades que possuíssem coletivamente ou individualmente, enquanto esse fosse seu desejo; entretanto, recebia dos maori o direito exclusivo de comprar as terras que eles quisessem vender. A versão inglesa garantia a posse de todas as propriedades, mas a versão maori garantia "tino rangatiratanga" (autoridade plena) sobre "taonga" (tesouros, não necessariamente o que fosse tangível). Assim, o que ambos os lados entendiam como "venda" das terras podia não coincidir. O terceiro artigo, finalmente, garantia aos maori os direitos e privilégios dos súditos britânicos, e sua tradução é considerada fiel.

$\mathrm{Na}$ noite em que o documento foi debatido, em 6 de fevereiro de 1840, os britânicos enfatizaram os benefícios do tratado e diminuíram a importância dos efeitos da soberania britânica sobre os chefes maori. Com a garantia de que seu status e sua autoridade seriam mantidos, muitos chefes aceitaram o acordo. Em 6 de fevereiro, o documento foi assinado por 40 chefes maori. Até setembro, outros quinhentos fizeram o mesmo, pois os britânicos percorreram as ilhas em busca das assinaturas, com diferentes cópias do documento, nas quais os chefes maori colocavam seu nome ou seu "moko" (marca facial ou corporal). Em 21 de maio, a soberania 
sobre a região foi proclamada. O escritório colonial na Inglaterra declarou mais tarde que o tratado se aplicava também às tribos que não o haviam assinado.

O empenho inglês em elaborar e traduzir o tratado e em obter a assinatura de grande número de chefes maori já é, por si só, uma questão interessante. É sabido que nem a coroa nem as companhias de colonização, ou os colonos individualmente, respeitaram o contrato. Freqüentemente as circunstâncias da compra de terras permaneceram obscuras, outras vezes os maori recusavam-se a vendê-las. Os conflitos levaram a guerras, que abriram caminho para confiscos. As tribos acabaram perdendo a base de seu sustento econômico e de sua organização social e cultural. Em 1865, após as principais guerras, criou-se uma instância jurídica exclusivamente voltada para regular as propriedades maori, o Native (depois Maori) Land Court, que passou a arrendar os terrenos que ainda restavam a indivíduos ou pequenos grupos, sem reconhecer a propriedade tribal, como queriam os maori. ${ }^{4}$

Para muitas tribos, esses conflitos representavam uma violação do Tratado de Waitangi; há registros de petições feitas ainda no século XIX para o Parlamento e a coroa, tendo como base o contrato firmado em 1840. Os Ngai Tahu, por exemplo, originários da ilha do Norte que acabaram se estabelecendo na ilha do Sul em meados do século XVIII, protestavam desde 1849, seja porque pedaços de terra ou reservas que a tribo gostaria de manter foram incluídas em áreas adquiridas pela New Zealand Company, seja porque a coroa não cuidou de escolas e hospitais, ou ainda arrendou terras e reservas para assentados europeus em caráter perpétuo sem o consentimento da tribo. ${ }^{5}$ Para os colonizadores e seus descendentes, contudo, o Tratado não tinha tanta importância. Até os anos 1970, era visto como uma curiosidade histórica. Por uma série de fatores, é nesse momento que se reacende o interesse pelo documento: ele passa a ser denunciado como farsa e o Tribunal de Waitangi, instalado em 1975, torna-se responsável por julgar as ações do governo que feriam o acordo histórico. 
Mas, antes de chegarmos a essa nova configuração, cabe observar este ponto: por que os britânicos se empenharam em firmar o acordo, se ele seria mesmo violado a seguir? Precisavam da formalidade? Talvez sim, para terem sua supremacia reconhecida não pelos maori, mas pelos franceses, que ameaçavam fixar-se na região.

Observação semelhante é feita por Stephen Greenblatt, em sua análise da primeira carta de Cristóvão Colombo aos reis da Espanha, relatando sua chegada, em 1492, àquilo que mais tarde seria conhecido como as ilhas do Caribe: "E lá encontrei numerosas ilhas, habitadas por incontáveis pessoas, e de todas elas tomei posse para Suas Altezas, por proclamação e com o estandarte real desfraldado, e não fui contradito." (apud GREENBLATT, 1989). A proclamação foi acompanhada da nomeação das ilhas - Colombo deulhes nomes, como se faz no batismo. Tomar posse, diz Greenblatt, "é evidentemente a realização de um conjunto de atos lingüísticos: declarar, testemunhar, registrar". Nomear, proclamar. Esses atos de fala foram feitos na presença do escrivão da frota, assegurando-se Colombo de que tudo seria escrito e, conseqüentemente, teria maior autoridade.

O curioso, contudo, é a idéia de que, em algum momento, a posse em nome da coroa espanhola poderia ser objetada pelos nativos. É o que dá a entender a frase "e não fui contradito", que não se refere aos espanhóis, mas aos nativos. Greenblatt observa com razão que Colombo levava a sério o fato de não ter sido contradito. Não se tratava, pois, de uma ironia. A formalização era importante para a Espanha, porque havia uma jurisprudência, desde o Código de Justiniano, que afirmava que a reivindicação sobre terras recém-descobertas seria legitimada pela "escolha voluntária" dos habitantes originais. Como era necessário respeitar a intenção do proprietário de transferir sua propriedade para outro, era preciso tomar posse com o conhecimento ou o consentimento do proprietário. Em glosa do jurista medieval Acúrsio, de meados do século XIII, já constava a frase "et non contradicente". O sentido da proclamação de Colombo aparece depois de seu retorno à Europa: 
quando a carta foi publicada em várias línguas, ela promulgou a reivindicação da Espanha, afirmando que o momento da contradição havia irrevogavelmente passado. Greenblatt observa: o ritual da posse atingiu, pois, seu pleno significado em relação às outras potências européias.

Ocorre que a proclamação e a posse da Espanha foram colocadas em xeque alguns anos depois, em 1530, conforme lembra Greenblatt, pelo teólogo Francisco de Vitória, que partiu dos princípios da lei natural para argumentar que os povos indígenas não tiveram seus direitos respeitados: "Os índios não sabiam o que estavam fazendo; mais ainda, eles não podiam ter entendido o que os espanhóis estavam pretendendo." (apud GREENBLATT, 1989). Essa talvez seja a razão pela qual os britânicos, passados trezentos anos, se esmeraram em traduzir o Tratado de Waitangi e em obter o máximo de assinaturas possível: para que não se objetasse sua posse das terras. Em 1840, agiam de acordo com uma jurisprudência que remontava ao direito romano, e o faziam para que sua soberania fosse reconhecida pelos demais europeus. Tanto é assim que o acordo com os maori não foi o único firmado entre colonizadores e "nativos" no período.

As políticas do governo britânico e, depois da independência, do governo neozelandês em relação aos maori foram guiadas, como se pode imaginar, pela idéia de superioridade dos europeus. ${ }^{7}$ Falava-se de assimilação e de integração, mas contanto que elas ocorressem em mão única: os maori aprendiam com os europeus e estes quase nada tinham a aprender com aqueles. ${ }^{8} \mathrm{O}$ resultado foi a desvalorização da língua, do sistema tribal e do conhecimento cultural dos maori, considerados irrelevantes para povos modernos no mundo. Como se viu no caso das resoluções do Native Land Court, o coletivismo das sociedades maori tinha de ser substituído pelo individualismo do progresso.

Até a Segunda Guerra Mundial, a maioria dos maori vivia em aldeias rurais, onde ainda se falava a língua maori. Em que pese a proibição de algumas práticas culturais - um ato de 1907, 
por exemplo, declarou criminosas todas as atividades espirituais e médicas dos sábios "tohunga" -, os conhecimentos e as tradições continuaram sendo transmitidos. No pós-1945, contudo, houve a promoção ativa, por parte do governo, da migração para as cidades, o que acelerou o processo de destribalização. Os migrantes eram encorajados a vender o que havia sobrado de suas terras ancestrais e a dar entrada em suas novas residências nas cidades. Muitos deles concordavam com essa "integração", pois assim preparariam melhor as novas gerações dos maori para o mundo.

Nos anos 1960, a marginalização do sistema cultural maori recrudesceu em função de um projeto de governo de cunho neodarwinista, elaborado no âmbito do Department of Maori Affairs, segundo o qual o governo não deveria ter papel algum na preservação da cultura maori, porque apenas os elementos culturais mais ajustados e os mais dignos seriam preservados para a civilização. Caberia exclusivamente aos maori, como indivíduos, decidir se determinada prática mereceria ser preservada. Um relatório escrito em 1960 por um integrante da Comissão do Serviço Público afirmava:

Only the Maoris themselves can decide whether these features of their ancient life are, in fact, to be kept alive; and in the final analysis, it is entirely a matter of individual choice. Every Maori who can no longer speak the language, perform the haka or poi [danças], or take his place on the marae [lugar sagrado], makes it just so much harder for these remnants of Maori culture to be perpetuated. (HUNN REPORT, apud WILLIAMS, 2004, p. 13)

Essa perspectiva de lidar com a questão sofreu uma mudança radical nas décadas seguintes. A gota d'água, que levou aos protestos dos anos 1970 responsáveis pelas mudanças nas políticas de governo, foi um ato do Parlamento de 1967 que aboliu o status das propriedades maori isentas de encargos, convertendo-as naquilo que era conhecido como "European land", e revogou todas

Anos 90, Porto Alegre, v. 14, n. 26, p.19-39, dez. 2007 
as proteções que haviam sido estabelecidas pelo Maori Land Court. O movimento, que teve início nas cidades e partiu principalmente de estudantes, chamou a atenção para o fracasso dos governos em honrar o Tratado de Waitangi. Houve uma intensa discussão pública sobre o tratado na Nova Zelândia e começaram a ser questionadas as políticas raciais no país, o qual até então era visto por muitos como aquele que desfrutava das melhores relações raciais no mundo. Inspirado pelos movimentos de libertação na África e pelas manifestações em defesa dos direitos civis nos Estados Unidos, o movimento maori guarda muitas semelhanças com o movimento negro contemporâneo no Brasil, também surgido no início dos anos 1970, que procurou questionar o chamado "mito da democracia racial".?

As primeiras manifestações ocorreram em 1971, no Waitangi Day, 6 de fevereiro, que hoje é um feriado nacional. No Brasil, também em 1971, começaram, no Rio Grande do Sul, as primeiras manifestações no dia 20 de novembro, dia da morte de Zumbi dos Palmares, que hoje se comemora como Dia da Consciência Negra. Houve protestos em 1972, e uma grande marcha ("hikoi") em 1975, quando cerca de 30 mil pessoas cruzaram a ilha do Norte até o Parlamento, em Wellington, protestando contra a perda continuada de terras maori. Entre 1977 e 1978, houve uma ocupação de terras que durou 506 dias e foi duramente reprimida pela polícia mais tarde o governo admitiu que se tratava de terra que havia sido adquirida de um grupo maori de forma ilegítima. ${ }^{10}$

Nesse contexto, em 1975 foi formado o Tribunal de Waitangi, para julgar demandas dos maori contra o Estado. ${ }^{11}$ Inicialmente, o tribunal julgou apenas ações referentes a acontecimentos ocorridos a partir de 1975, mas dez anos depois, em 1985, passou a julgar ações que remontam a 1840. Transformou-se, pois, num tribunal histórico, encarregado de julgar crimes do passado e de, portanto, fazer política no presente. Entramos no terreno do que 
passou a ser conhecido como "dever de memória", conceito discutido por Luciana Heymann em artigo recentemente publicado. Trata-se de expressão cunhada na França nos anos 1990, que "traduz a idéia de que as memórias de sofrimento e opressão geram obrigações, por parte do Estado e da sociedade, em relação às comunidades portadoras dessas memórias" (HEYMANN, 2007, p. 18). O alemão Gerd Hankel, teórico da literatura e doutor em direito, que trabalha desde 2002 na região dos Grandes Lagos, na África, e acompanha o julgamento dos responsáveis pelo genocídio de Ruanda (1994), escreveu um artigo intitulado "Passado que não pode sossegar" (HANKEL, 2006). Nele, observa que há muitas formas de se lidar com o passado, mas que o uso do direito, apesar de ser apenas um dos elementos na valorização política e moral do passado, é talvez a forma mais importante, porque permite chamar o crime de crime e enquadrar as análises e os relatos da história. Por exemplo, os chefes nazistas não foram festejados como heróis nacionais pelas gerações seguintes, como previu Hermann Göring, ainda durante seu julgamento do Tribunal de Nuremberg. O desafio aqui é que os processos judiciais precisam da verdade, sem a qual não é possível determinar quem fez o quê, contra quem e quando. Sem verdade, diz Hankel, não há Justiça para as vítimas (e tampouco para os culpados). E, sem Justiça e a conseqüente reparação, a reconciliação torna-se apenas uma palavra bemintencionada. É interessante observar como, nos tribunais históricos que surgiram nessa nova configuração do "dever de memória", os historiadores e antropólogos estão sendo chamados para estabelecer "a verdade". É o caso, por exemplo, dos processos contra criminosos nazistas, que ocorreram na França nos anos 1970 e 1980, nos quais historiadores depuseram como experts (DAMAMME; LAVABRE, 2000, e HEYMANN, 2007), e dos laudos antropológicos que, no Brasil, visam a atestar a existência de terras "remanescentes de quilombos", como estabelecido pela Constituição de 1988 (ARRUTI, 2006). 
Giselle Byrnes (1998), que trabalhou para o Tribunal de Waitangi como historiadora de 1995 a 1996, observou que a instituição foi responsável por uma demanda sem precedentes de serviços de historiadores, contratados por grupos maori, pelo governo e pelo próprio Tribunal para realizar pesquisas nas fontes relativas aos processos, preparar relatórios, apresentar provas e atuar como testemunhas especializadas. Segundo ela, os historiadores foram levados diretamente para o território do discurso legal e as evidências históricas passaram a se tornar objeto de escrutínio jurídico e, eventualmente, de litígio. Isso acabou informando o modo como os historiadores praticam a história, uma vez que passaram a se envolver diretamente com o que vai acontecer, e não somente com o que aconteceu.

As implicações dessa atuação no espaço público não são simples. Em artigo intitulado "La vérité, le temps, le juge et l'bistorien" (1998), Yan Thomas pergunta-se até que ponto o historiador se distancia do juiz quando o desenho que ele traça do contexto das ações que ele se recusa a julgar serve precisamente para qualificar essas ações como crimes. E lembra que, no caso de crimes contra a humanidade - como são definidos o holocausto e o genocídio -, essa inclusão do contexto no ato é essencial para sua definição jurídica (apud DAMAMME; LAVABRE, 2000, p. 13). A esse respeito, é interessante observar que, em 1996, houve um acirrado debate por causa do uso da palavra "holocausto" em um relatório do Tribunal de Waitangi, que se referia assim às políticas do governo colonial do século XIX, de guerras, confiscos de terra e invasão de comunidades (WILLIAMS, 2004, p. 8; BYRNES, 1998, p. 21). Como observa Luciana Heymann, as lutas em torno dessas denominações ("geno-cídio", "etnocídio", "holocausto", "crime contra a humanidade") traduzem a tentativa de expressar a incomensurabilidade do sofrimento de vítimas de tragédias históricas, mas também sugerem uma escala de vitimização (HEYMANN, 2007, p. 28). 
Em um interessante texto sobre mitos e origem nacional, David Williams, professor da Faculdade de Direito da Universidade de Auckland, lembra que a expressão "genocídio cultural" é usada com alguma freqüência para qualificar as ações do Estado que levaram à marginalização e ao esquecimento de práticas culturais dos maori (WILLIAMS, 2004, p. 8). Como medida das mudanças que se implantaram na Nova Zelândia a partir dos anos 1970, vale observar que o "dever de memória" relacionado a esse "genocídio" gerou uma reparação fundamental por parte do Estado: o reconhecimento, em 1987, do maori como língua oficial. A medida legal foi justificada, em seu preâmbulo, com base no Tratado de Waitangi: se, em 1840, a coroa garantiu aos maori todos os seus tesouros ("taonga"), e se a língua maori é um desses tesouros, então cabe ao Estado (com mais de cem anos de atraso, podemos acrescentar) garantir que a língua não se extinga. Ela passa a fazer parte da identidade nacional da Nova Zelândia. O museu nacional Te Papa (traduzido por "Our place") chama-se, na versão completa do nome, Te Papa Tongarewa (algo como "The place of treasures of this land"). Trata-se, como temos visto ao longo deste texto, de todo um movimento que procura repensar a identidade nacional, que, como lembra Eric Hobsbawm (1990, p. 20), pode mudar, e em períodos muito curtos.

Em contraposição ao "genocídio cultural" fala-se agora de um "renascimento cultural" dos maori. Byrnes estima que, em 1997, da população total da Nova Zelândia de mais de 3,5 milhões, cerca de 580 mil, isto é, 16,6\% reivindicavam uma ancestralidade maori. Esse movimento é tão penetrante, diz Williams, que em muitos casos precisa ser reportado em seus próprios termos e em sua própria linguagem. Palavras e expressões em maori passaram a fazer parte do cotidiano dos neozelandeses em sua comunicação oral e escrita. Freqüentemente, a palavra Aotearoa, que acabou se tornando o nome maori para designar todo o país, aparece ao lado de "New Zealand". Mas o caso de "pakeha" é o 
que talvez mais chame a atenção. Trata-se do termo maori para o colonizador europeu e seus descendentes, e tornou-se a designação utilizada por muitos descendentes de europeus favoráveis às mudanças implementadas no país a partir dos anos 1970. Os que discordam das mudanças não se identificam como "pakeha". A palavra já aparece em vários textos sem qualquer sinal que a identifique como estrangeira (aspas ou itálico, por exemplo).

Aproximemo-nos agora um pouco do funcionamento do Tribunal de Waitangi. Ele é composto por até 16 membros, pakeha ou maori, e mais o juiz chefe do Maori Land Court. Até 1988 a maioria precisava ser maori. Trata-se de pessoas que devem ter conhecimento e experiência na área, alguns formados em história ou em direito, podendo ser também os "mais velhos" de grupos maori, ou até empresários. ${ }^{12} \mathrm{O}$ Tribunal não julga ações contra propriedades privadas, apenas contra terras que a coroa, ou seja, o Estado, tenha adquirido indevidamente. ${ }^{13}$ Os demandantes devem ser maori - um indivíduo, uma tribo ("iwi"), uma subtribo, ou uma família extensa. Os processos levam, em geral, muito tempo até serem concluídos. De acordo com Theron (1998), requisições de terra são assunto sensível, profundamente ligado a seu contexto histórico e envolvem questões conflitivas e concepções de terra também conflitivas. Por isso há uma defasagem significativa entre a audiência e o relatório final.

O Treaty of Waitangi Act, que criou o Tribunal em 1975, reconhece o texto maori do tratado, junto com o texto inglês, como parte da lei neozelandesa e faz referência, em seu preâmbulo, aos "princípios do Tratado de Waitangi". Contudo, como o Parlamento não havia definido quais eram esses princípios, o Tribunal e as demais cortes de Justiça acabaram tendo que criar seu significado - Williams fala de uma verdadeira "invenção" desse significado -, sempre ajustado aos propósitos de suas determinações. ${ }^{14}$ Alguns críticos desse processo acusaram o Tribunal de legislar no lugar do Parlamento mas, com o tempo, criou-se uma jurisprudência sobre 
o assunto. Um levantamento feito em 2001 mostrou que, então, já havia 32 atos do Parlamento relativos a diferentes assuntos que incorporavam uma referência direta ao Tratado ou a seus "princípios". Todas essas decisões fizeram com que o Tratado alcançasse um novo status: de uma simples nulidade, mera curiosidade histórica praticamente ausente dos currículos escolares, passou a um documento quase constitucional na vida da nação.

Dissemos acima que julgamentos num tribunal histórico, encarregado de julgar crimes do passado, precisam da verdade. Como se estabelece a verdade no caso do Tribunal de Waitangi? Aqui nosso tema torna-se ainda mais interessante, pois a tradição oral passa a fazer parte do processo judicial, sendo entendida como evidência. Mas, antes de analisarmos esse aspecto, cabe ressaltar uma outra valorização (antes impensável) da oralidade. Como, em 1840, a linguagem oral era central para os maori, considera-se hoje que as explicações dadas aos maori pelos missionários e por outros representantes da coroa britânica na noite do dia 6 de fevereiro de 1840 foram provavelmente tão ou mais importantes que o documento escrito. Por isso, prevalece juridicamente, hoje, a interpretação do tratado da tradução maori.

Nesse particular, observa-se uma semelhança bastante grande com o que se passa no Canadá, onde desde 1982 os tratados firmados entre aborígenes e a coroa nos séculos XVIII e XIX e no início do século XX são considerados documentos constitucionais. ${ }^{15}$ Em 1999, a Suprema Corte canadense decidiu que, ao interpretar os textos desses tratados, era necessário compreender como ambas as partes entenderam, no passado, o instrumento jurídico. Um deles, por exemplo, firmado em Alberta em 1877, foi entendido pelos indígenas como um tratado de paz, e não como uma cessão de terras. Os indígenas concordaram em partilhar a terra e os recursos naturais com os europeus, em troca de educação, reservas indígenas e assistência médica. Várias promessas que não ficaram escritas foram feitas aos aborígenes e, hoje, é preciso 
considerar a tradição oral de grupos indígenas e outras evidências extrínsecas para estabelecer o sentido que esses documentos tiveram no momento de sua assinatura. Leslie (2002) observa com razão que essa contextualização dos documentos traz novos desafios para historiadores e arquivistas.

Mas como a tradição oral aparece como evidência em um julgamento no Tribunal de Waitangi? Em 1999, o Tribunal publicou uma brochura, de autoria de um historiador, que explica como devem ser preparadas as provas, ou evidências, de um processo (PHILLIPSON, 1999). O livreto é bastante didático. Em primeiro lugar, explica que as demandas só devem ser feitas se forem cumpridos os seguintes requisitos: 1) a coroa rompeu o Tratado de Waitangi com ações (ou omissões), leis ou políticas; 2) os maori sofreram prejuízos em conseqüência da ação (ou omissão) da coroa.

As demandas devem conter relatórios de dois tipos: o relatório sobre a "história tradicional" ("traditional history report") e o relatório histórico, a ser elaborado por um historiador profissional. Os relatórios precisam basear-se em evidências, as quais terão de ser acrescentadas ao processo. A pesquisa para a história tradicional deve ser feita em fontes orais e escritas. Exemplos de evidências orais são entrevistas com os "mais velhos", anciãos dos grupos maori, tanto homens ("kaumatua") quanto mulheres ("kuia"). Entre as evidências escritas sugeridas, estão atas da Maori Land Court, documentos de arquivo (correspondência de missionários, papéis oficiais do século XIX) e livros de genealogia.

As evidências orais do relatório de "história tradicional" devem ser: 1) tradições orais sobre ações da coroa desde 1840 e testemunhos das ações mais recentes (por exemplo, obras públicas que, nos anos 1960, desalojaram grupos maori) e que fazem parte da memória viva ("living memory") dos informantes; 2) tradições orais e "memórias vivas" sobre o impacto e o prejuízo causados pelas ações da coroa. Essas evidências orais precisam ser registradas em entrevistas gravadas e transcritas, e devem estar 
disponíveis tanto para os historiadores quanto para o tribunal, que pode solicitar que sejam novamente apresentadas pelos informantes durante a audiência. Os juízes contam com a ajuda de um "mais velho", que os aconselha na interpretação das evidências tradicionais. Ao mesmo tempo, um historiador profissional exerce a mesma função em relação à interpretação das evidências históricas.

$O$ fato de a tradição oral passar a ser legitimada no campo jurídico e nas políticas de Estado é um fenômeno recente. ${ }^{16} \mathrm{O}$ interessante é que uma característica tida como não-ocidental (a tradição oral) ingressa no campo do direito (ocidental, por excelência) e aí passa a valer como lei. Como observa o antropólogo José Maurício Arruti, com relação ao processo de reconhecimento das terras dos "remanescentes de quilombos" no Brasil, nos quais são exigidas "provas" acerca da ancestralidade indígena ou quilombola dos moradores: " $\mathrm{Na}$ falta das tais 'evidências históricas', a memória passa a figurar como "prova", o que "significou estabelecer uma relação nova entre 'direitos' e memória, desconhecida até então" (ARRUTI, 2006, p. 218).

Mas precisamos tomar cuidado para não operar com dicotomias simplificadoras do tipo "oral" versus "escrito", "tradição genuína" versus "modernidade ocidental". A análise de Laura Millar (2006) dos registros aborígenes e não-aborígenes na história do Canadá pode nos ajudar nesse sentido. Millar descreve como a tradição oral dos mais de 150 grupos aborígenes da província de British Columbia, além de registrar as negociações que eram feitas quando da assinatura dos tratados com a coroa britânica, servia para atualizar os registros escritos dos oficiais do governo, que "traduziam" elementos da tradição oral em forma escrita, para uso dos ocidentais. A legitimidade desses testemunhos orais em registros do governo era tão grande que alguns oficiais menos escrupulosos faziam sumir os documentos do governo para não respeitar os direitos dos indígenas. $\mathrm{E}$, no final do século $\mathrm{XX}$, quando os aborígenes passam a precisar juntar provas para fundamentar suas 
petições nos tribunais canadenses, é aos arquivos dos departamentos de assuntos indígenas que recorrem, para copiar e guardar registros escritos e evidências documentais que seus ancestrais ajudaram a criar. O texto de Millar mostra, pois, a inextricável ligação entre duas formas de comunicação, de documentação e de construção da memória, lembrando, como já o fizeram Jack Goody e Ian Watt (1968), que não há fronteiras claras entre culturas escritas e não-escritas.

Nesse sentido, talvez possamos dizer que o ingresso da tradição oral no campo do direito responde menos a uma necessidade de representação dos aborígenes, dos quilombolas, dos grupos "sem escrita", do que ao reconhecimento dos benefícios que pode trazer a esferas administrativas e legais. $\mathrm{O}$ testemunho oral tornou-se necessário para fazer valer o direito. $\mathrm{Na}$ mesma direção caminha a incorporação de práticas culturais maori - língua, tradições etc. na vida social; não por acaso elas passaram a fazer parte do currículo escolar, desde o jardim de infância até a graduação.

A despeito de todo cuidado necessário para evitar polarizações simplificadoras, não há dúvida de que as ações de tribunais como o de Waitangi acabam "empoderando" (como passou a ser comum traduzir "to empower") os grupos que são objeto das reparações. E não só eles, como os profissionais envolvidos nos processos: advogados, historiadores, antropólogos. O efeito das decisões muitas vezes incide sobre a identidade dos grupos. Giselle Byrnes (1998) observa que, quando não há provas por parte da coroa e o Tribunal decide a favor dos maori, os demandantes acabam considerando o relatório publicado pela corte como "sua história".

Nesse processo, algumas decisões ou possibilidades de decisão acabam gerando polarizações ácidas dentro da própria sociedade. No Brasil, isso ocorre atualmente com o debate muitas vezes acirrado em torno das ações afirmativas e da reserva de vagas para negros nas universidades. No Canadá, a polarização foi causada 
por duas decisões tomadas pela Suprema Corte, uma em 1999 e a outra em 2002. Na primeira, decidiu-se não condenar o membro de uma reserva indígena que foi preso vendendo peixe ilegalmente, com base no argumento de que as negociações de tratados firmados com os indígenas no século XVIII previram o direito de os indígenas pescarem, caçarem e plantarem e de fazerem comércio com os colonizadores. $\mathrm{Na}$ segunda, a corte admitiu o testemunho oral de mais velhos como evidência de que houve promessa de isenção de impostos quando da assinatura de um tratado com os aborígenes. Houve muita reação a essa decisão, vista como sendo baseada na etnia, e não numa obrigação contratual histórica. As reações violentas a ambas as resoluções revelam, como observa Leslie (2002, p. 129), que o papel e o impacto público de pesquisas históricas e de testemunhos especializados podem ter conseqüências imprevisíveis.

Na Nova Zelândia, dois acontecimentos recentes provocaram reações semelhantes. ${ }^{17}$ Em 2003, a Corte de Apelação reconheceu que as tribos maori poderiam trazer suas reivindicações sobre as praias e o fundo do mar, mas que caberia ao Maori Land Court decidir sobre os direitos a respeito. Apesar dessa decisão modesta, a reação foi grande e controversa: em rádios, cartas de leitores e outros meios dizia-se que os maori estariam clamando por direitos exclusivos, que colocariam em xeque o acesso público a praias. Em janeiro do ano seguinte, ocorreu um debate nacional sobre o Tratado de Waitangi, a partir de um discurso do líder da oposição, Don Brash, que criticava os "privilégios raciais", integração que proclamavam "we are one people". Para ele, o Tratado nunca foi crucial para a fundação do estado colonial; sempre foi periférico para a aquisição da soberania britânica sobre a Nova Zelândia. Ele sempre foi, pois, uma fraude. Mas nas décadas recentes, o mito do Tratado como pedra fundadora nacional teve um desenvolvimento muito positivo na emergência de uma sociedade plural, na qual o status dos maori como "tangata whenua", isto é, 
como os primeiros que se fixaram na Nova Zelândia, foi reconhecido. Isso contribuiu para "empoderar" tribos e grupos maori e permitiu um processo de conciliação cultural entre maori e pakeha. Segundo ele, "we are in national myth-making times" e, nesse sentido, o Tratado deve ser considerado documento fundador da identidade nacional, mesmo que não o tenha sido.

Oral tradition and memory uses: the case of the Waitangi Tribunal, New Zealand

Abstract: In 1840 the Treaty of Waitangi, between the British Crown and more than 500 Maori heads was signed in New Zealand, then a British colony. In its three articles, the document, written in English and translated into Maori by British missionaries, states that the Maori would cede the region's sovereignty to Britain, having guaranteed their right over lands, forests and fisheries. In New Zealand's history, however, the Treaty has not been honored and the Maori gradually lost their lands and were confined to remote and rugged regions. In the 1970s a set of factors led to Maori mobilizations, which culminated in the creation of the Waitangi Tribunal, in 1975. The tribunal receives claims concerning actions or omissions of the British Crown which consist in a breach of the 1840 Treaty. At the trial, the "oral evidences", e.g., the oral tradition of the groups which claim for land or the right to an economic activity, have an important role. This paper intends to be an approach to the case of the Waitangi Tribunal, which allows us to establish relations between oral tradition, uses of the past and national identity.

Keywords: Memory. Oral tradition. Uses of the past. National identity. New Zealand.

\section{Notas}

${ }^{1}$ Uma primeira versão deste texto foi apresentada no IX Encontro Nacional de História Oral, realizado na Universidade do Vale do Rio dos Sinos (UNISINOS), em São Leopoldo (RS), de 22 a 25 de abril de 2008. Agradeço a Luciana Quillet Heymann, também pesquisadora do CPDOC, que discutiu o assunto comigo e me indicou leituras importantes: Greenblatt, 1989; Damamme; Lavabre, 2000; Leslie, 2002, e Millar, 2006. E as famílias Mautner e Gilbert, meus parentes que me acolheram na Nova Zelândia em julho de 2006, quando o XIV Congresso Internacional de História Oral me levou para a Austrália, e assim permitiram minha incursão no tema do Tribunal de Waitangi.

Anos 90, Porto Alegre, v. 14, n. 26, p.19-39, dez. 2007 
${ }^{2}$ http://www.tepapa.govt.nz/TePapa/English/AboutTePapa/AboutUs / Our+History.htm.

${ }^{3}$ Sobre o tratado e sua história, ver The Treaty of Waitangi Information Programme, 2004 e 2005; Durie (1993); Byrnes (1998).

${ }^{4}$ Ver Durie, 1993, p. 2, e Williams, 2004, p. 7. A tradição do direito ocidental não prevê a propriedade coletiva de terras. À semelhança do que ocorreu na Nova Zelândia, essa característica causou dificuldades no processo de reconhecimento das terras dos chamados "remanescentes de quilombos" no Brasil após a Constituição de 1988. Em 2003, o Decreto n. 4.887, finalmente deu direito à propriedade coletiva dos quilombos. Ver entrevista de Josilene Brandão em Alberti e Pereira, 2007, p. 316.

${ }^{5}$ Ver http://www.nzhistory.net.nz/politics/treaty/the-treaty-in-practice/ngai-tahu. ${ }^{6}$ A coroa britânica firmou outros tratados com "nativos" nesse período. Por exemplo, com líderes tribais de Gâmbia, o British Sherbo Agreement de 1825, e com aborígenes da região de British Columbia, no atual Canadá. Ver Byrnes, 1998; Leslie, 2002, e Millar, 2006.

${ }^{7}$ A Nova Zelândia tornou-se uma nação autônoma dentro da Comunidade Britânica em 1907 e obteve a independência em 1947.

${ }^{8}$ Sobre esse processo, ver Williams, 2004.

${ }^{9}$ Sobre o movimento negro contemporâneo no Brasil, ver Alberti e Pereira, 2007.

${ }^{10}$ Essas e outras informações podem ser obtidas em www.nzhistory.net.nz.

${ }^{11}$ Um ano antes, em 1974, foram revertidas as decisões do Maori Affairs Act de 1967 (ver WILLIAMS, 2004).

${ }^{12}$ Theron, 1998.

${ }^{13}$ Como a Nova Zelândia, ainda que independente, continua sendo uma monarquia, cuja rainha é Elizabeth II, da Inglaterra, é comum a referência à "coroa" como sinônimo de "Estado".

${ }^{14}$ Ver, a esse respeito, Williams, 2004.

${ }^{15}$ Ver Leslie, 2002, e Millar, 2006.

${ }^{16}$ Além do Canadá, os Estados Unidos são outro exemplo de país em que a tradição oral passou a ser vista como elemento de prova no julgamento de processos envolvendo grupos indígenas. Ver Neuenschwander, 2004.

${ }^{17}$ Ver Williams, 2004.

\section{Referências}

ALBERTI, Verena; PEREIRA, Amilcar Araújo. Histórias do movimento negro no Brasil. Rio de Janeiro: Pallas Editora, CPDOC, 2007.

ARRUTI, José Maurício. Mocambo: antropologia e história do processo de formação quilombola. Bauru, São Paulo: Edusc, 2006.

Anos 90, Porto Alegre, v. 14, n. 26, p.19-39, dez. 2007 
Tradição oral e usos da memória: o caso do Tribunal de Waitangi, Nova Zelândia

BYRNES, Giselle M. Jackals of the Crown? Historians and the Treaty Claims Process in New Zealand. The Public Historian. University of California Press, v. 20, n. 2, Spring 1998, p. 9-23.

DAMAMME, Dominique; LAVABRE, Marie-Claire. Les historiens dans l'espace public. Sociétés Contemporaines. Centre National de la Recherche Scientifique. Paris, n. 39, p. 5-21, 2000.

DURIE, E. T. J. A New Zealand Maori View. The knowledge basket New Zealand's research archive. June 1993. Disponível em: < http:// www.knowledge-basket.co.nz/ oldwaitangi/press/93africa.HTM>.

GOODY, Jack; WATT, Ian. The Consequences of Literacy. In: Goody, Jack (ed.). Literacy in traditional societies. Cambridge: Cambridge University Press, 1968. p. 27-68.

GREENBLATT, Stephen. Maravilhosas possessões. Estudos Históricos. Rio de Janeiro, v. 2, n. 3, p. 43-62, 1989.

HANKEL, Gerd. Vergangenheit, die nicht ruhen darf. Aus Politik und Zeitgeschichte. Beilage zur Wochenzeitung Das Parlament. 42/2006, 16. Oktober 2006, p. 3-9.

HEYMANN, Luciana Quillet. O devoir de mémoire na França contemporânea. In: Gomes, Angela de Castro (coord.). Direitos e cidadania: memória, política e cultura. Rio de Janeiro: Editora FGV, 2007, p. 15-43.

HOBSBAWM, Eric. Nações e nacionalismo desde 1780: programa, mito e realidade. Rio de Janeiro: Paz e Terra, 1990 (palestras proferidas em 1985, em Belfast).

LESLIE, John F. The Importance of Oral and Extrinsic Historical Evidence in Understanding. Archivaria. The Journal of the Association of Canadian Archivists. n. 53, Spring 2002, p. 122-129.

MILLAR, Laura. Subject or object? Shaping and reshaping the intersections between aboriginal and non-aboriginal records. Archival Science. Springer Netherlands. v. 6, p. 329-350, December, 2006.

NEUENSCHWANDER, John A. Native American Oral Tradition: History as Evidence in American Federal Courts. Trabalho apresentado no XIII Congresso Internacional de História Oral. Roma, 23-26 junho 2004.

PHILLIPSON, Grant. Preparing Claimant Evidence for the Waitangi Tribunal. Waitangi Tribunal, 1999. Disponível em <http://www.waitangitribunal.govt.nz/ claims/evidence.asp $>$.

THERON, Liesle. Healing the Past: a Comparative Analysis of the Waitangi Tribunal and the South African Land Claims System. Victoria University of Wellington Law Review. v. 15, 1998. Disponível em < http://www.austlii.edu.au/nz/journals/ VUWLRev/1998/15.html\#fn122)>

Anos 90, Porto Alegre, v. 14, n. 26, p.19-39, dez. 2007 
THE TREATY OF WAITANGI INFORMATION PROGRAMME. The Story of the Treaty (Part 1 e Part 2). Wellington, State Services Commission, 2005.

THE TREATY OF WAITANGI INFORMATION PROGRAMME. Timeline of the Treaty. Wellington, State Services Commission, 2004.

THE TREATY OF WAITANGI INFORMATION PROGRAMME. All about the Treaty. Wellington, State Services Commission, 2005.

THE TREATY OF WAITANGI INFORMATION PROGRAMME. The Journey of the Treaty. Wellington, State Services Commission, 2005.

WILLIAMS, David. Myths, National Origins, Common Law and the Waitangi Tribunal. Paper presented at the 23rd Annual Australia and New Zealand Law and History Society Conference, Murdoch University, Western Australia, 2-4th July, 2004 (http://www.murdoch.edu.au/elaw/issues/v11n4/williams114_text.html).

Recebido em 24/03/2008.

Autora convidada. 